\title{
Article \\ ESBL/AmpC-Producing Enterobacteriaceae Fecal Colonization in Dogs after Elective Surgery
}

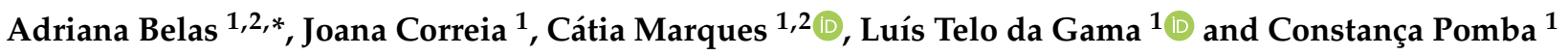 \\ 1 Centre for Interdisciplinary Research in Animal Health (CIISA), Faculty of Veterinary Medicine, \\ University of Lisbon, Avenida da Universidade Técnica, 1300-477 Lisbon, Portugal; \\ joanacorreia@fmv.ulisboa.pt (J.C.); adcatiamarques@fmv.ulisboa.pt (C.M.); ltgama@fmv.ulisboa.pt (L.T.d.G.); \\ cpomba@fmv.ulisboa.pt (C.P.) \\ 2 Faculty of Veterinary Medicine, Lusófona University, Campo Grande, 1749-024 Lisbon, Portugal \\ * Correspondence: adrianabelas@fmv.ulisboa.pt or adriana.belas@ulusofona.pt
}

check for

updates

Citation: Belas, A.; Correia, J.; Marques, C.; da Gama, L.T.; Pomba, C. ESBL/AmpC-Producing

Enterobacteriaceae Fecal Colonization in Dogs after Elective Surgery. Microbiol. Res. 2021, 12, 907-915. https://doi.org/10.3390/microbiolres 12040067

Academic Editor: Beniamino

T. Cenci-Goga

Received: 1 September 2021

Accepted: 22 November 2021

Published: 24 November 2021

Publisher's Note: MDPI stays neutral with regard to jurisdictional claims in published maps and institutional affiliations.

Copyright: (c) 2021 by the authors. Licensee MDPI, Basel, Switzerland. This article is an open access article distributed under the terms and conditions of the Creative Commons Attribution (CC BY) license (https:/ / creativecommons.org/licenses/by/ $4.0 /)$.

\begin{abstract}
The purpose of this study was to evaluate the presence and load of ESBL/AmpC-producing Enterobacteriaceae fecal carriage in healthy dogs. Fecal samples were collected from dogs submitted to surgical procedures $(n=25)$. Fecal samples were collected before surgery (BS) and after surgery (AS). $\beta$-lactamases were detected by PCR. Statistical analyses were performed with SAS software (v.9.4); a $p$ value $\leq 0.05$ was considered statistically significant. The ESBL/AmpC-producing Enterobacteriaceae bacteria species detected in this study were E. coli, K. pneumoniae and E. cloacae. TEM, and CTX-M-1 group genes were the most frequent $\beta$-lactamases detected. The number of dogs colonized with 3GC-resistant Enterobacteriaceae bacteria was significantly higher in the AS (63.6\%, $n=14 / 22)$ group compared to in the BS group $(20.0 \%, n=5 / 25, p=0.0033)$. The ESBL/AmpCproducing bacteria fecal load was significantly higher in the AS group compared to in the BS $(p=0.025)$ group. This study shows that 3GC-resistant Enterobacteriaceae and ESBLs/AmpC producers in the veterinary clinical practice are a concern and highlights the need to implement preventive measures to minimize their spread.
\end{abstract}

Keywords: veterinary hospitals; antimicrobial prophylactic use; ESBLs; pAmpC; third generation cephalosporin resistance; gut colonization

\section{Introduction}

The European Medicine Agency has reviewed the public health risks associated with the transfer of antimicrobial resistance from companion animals and has identified the major microbiological hazards coming from companion animals to humans, including thirdgeneration cephalosporin-resistant bacteria [1]. The presence of antimicrobial-resistant bacteria in companion animals and their close contact with humans provides opportunities for interspecies transmission [1]. In veterinary hospitals, infections acquired during hospitalization caused by resistant bacteria are an increasing problem [2,3]. Antimicrobials are regularly used for the prevention and control of infections in companion animals, and many of the antimicrobials used are the same or closely related to those used in the treatment of bacterial infections in humans [4,5].

$\beta$-lactams are among the most important antimicrobials used in veterinary medicine. Extended-spectrum $\beta$-lactamases (ESBLs) are enzymes that confer resistance to most betalactam antibiotics, including penicillins, cephalosporins, and the monobactam aztreonam except for cephamycins and carbapenems [6]. In addition to ESBLs, Enterobacteriaceae can acquire plasmid-encoded ampC genes (pAmpC) as an important resistance mechanism against $\beta$-lactams. AmpC $\beta$-lactamases hydrolyze several $\beta$-lactam antibiotics, including cephamycins, oxyimino cephalosporins, and monobactam aztreonam [7]. ESBL/AmpCencoding genes are located on mobile genetic elements, and many are plasmid-mediated and transferable between bacteria of different species. The first ESBLs were described 
in Europe in the 1980s, and since then, ESBLs have been reported worldwide as a major source of antimicrobial resistance in Gram-negative pathogens [6,8]. The most frequent ESBL producers are Escherichia coli and Klebsiella pneumoniae, which are the main source of community- and hospital-acquired infections in human and veterinary medicine [6,8,9].

Prophylactic antimicrobial use involves the administration of the antimicrobial in the absence of infection, with the aim of preventing it, for example in the perioperative period [5]. Ideally, the antimicrobial prophylaxis scheme should be selected and prescribed to minimize the possible impact on the normal bacterial flora of the patient and on the microbiologic ecology of the hospital [10]. Inappropriate prophylaxis may promote the selection of antimicrobial-resistant bacteria [5].

The gastrointestinal tract is one of the main reservoirs for the emergence and dissemination of antimicrobial-resistant bacteria. Dog feces are a recognized source of resistant bacteria that can be transmitted to humans through direct contact or through shared (domestic and public) environments [1,10-16]. Antimicrobial resistance to third generation cephalosporins (3GC) has been previously detected in bacteria from canine fecal samples in recent years [14,15,17-20]. However, to the best of our knowledge, this is the first study to focus on the dynamics of ESBLs/AmpC producing- Enterobacteriaceae in the intestinal tracts of healthy dogs that were admitted to perform elective surgical procedures. The purpose of this study was to evaluate the presence and load of ESBLs/AmpC-producing Enterobacteriaceae fecal carriages in healthy dogs undergoing surgery.

\section{Materials and Methods}

\subsection{Sampling Procedure and Collection of Data}

From February to July 2014, fecal samples were obtained from 25 healthy dogs (without signs of gastrointestinal disease in the previous week) that went to a veterinary teaching hospital to undergo a surgical procedure. The surgery study group was divided: (i) before surgery (BS) upon admission to the Veterinary Hospital and (ii) after the surgical procedure (AS). Animals were excluded if they had been treated with an antimicrobial agent in the previous month. The surgical procedures considered for this study were soft tissue and orthopedic surgery. Fecal samples were collected at two different time points, namely before (BS) and after surgery (AS). A total of 25 animals were included in the BS group. The follow up samples included in the AS group were collected one week after surgery. However, in three animals, the follow-up was not possible and, therefore, 22 samples were studied. The dog owners were questioned verbally, and all replied to the questions regarding: age, gender, hospitalization, and antimicrobial treatment within the last year, cohabitation with other animals, street access, shelter/hotel access, and surgery type (soft tissue, orthopedic) and surgery reason (elective surgery or non-elective). The fecal sample collection was conducted by the owners using non-invasive methods. Owners were given specific instructions about the collection method to avoid sample contamination through contact with the ground. The instructions also included the fecal collection into sterile containers and the use of gloves.

\subsection{Bacteria Isolation, Identification and DNA Extraction}

One gram of feces was diluted in sterile saline solution ( $\mathrm{NaCl}, 0.85 \%$-Merck-Germany). Once homogenized, $10 \mu \mathrm{L}$ was directly cultured on MacConkey agar plates (Scharlau, Barcelona, Spain) supplemented with $2.0 \mu \mathrm{g} / \mathrm{mL}$ of cefotaxime (CTX) (Sigma-Aldrich, St. Louis, MO, USA) and incubated overnight at $37^{\circ} \mathrm{C}$. CTX-resistant Enterobacteriaceae bacteria were then quantified by counting the colony-forming units (CFU) per gram of feces. Positive samples were screened for the presence of different colony morphologies of CTX-resistant Enterobacteriaceae. One isolate of each unique morphology was selected from each positive sample for further study. The bacterial species were determined using an API 20E kit, the software APIWEB (BioMérieux, Marcy-l'Étoile, France) and by species-specific PCR [21,22]. DNA extraction was conducted using a boiling method [23]. 


\subsection{Escherichia coli Phylogenetic Typing}

Phylogenetic typing was performed in all E. coli isolates to determine the main phylogenetic groups (A, B1, B2 and D) according to the amplification of chuA and yjaA genes, and TspE4C2 fragment) by multiplex PCR [24].

\subsection{Antimicrobial Susceptibility Testing}

Antimicrobial susceptibility testing and interpretation were performed using the disk diffusion method according to Clinical and Laboratory Standards Institute (CLSI) guidelines [25]. The following antimicrobial disks (Oxoid, Basingstoke, Hampshire, UK) were used: $10 \mu \mathrm{g}$ ampicillin (AMP), $30 \mu \mathrm{g}$ amoxicillin-clavulanate (AMC), $30 \mu \mathrm{g}$ cephalothin (KF), $30 \mu \mathrm{g}$ cefotaxime (CTX), $30 \mu \mathrm{g}$ ceftazidime (CAZ) and $30 \mu \mathrm{g}$ cefoxitin (FOX). ESBL production was confirmed by the double-disk synergy test according to CLSI standards and isolates were classified as susceptible or resistant according to CLSI criteria [25]. The reference strain E. coli ATCC 25922 was used for quality control testing [25].

\section{5. $\beta$-Lactamase Resistance Genes}

3GC-resistant Enterobacteriacea isolates were screened by PCR for the presence of $b l a_{\mathrm{SHV}}, b l a_{\mathrm{OXA}-1}, b l a_{\mathrm{TEM}} \beta$-lactamase genes; $b l a_{\mathrm{CTX}-\mathrm{M}}, b l a_{\mathrm{CTX}}$-M-1group and bla $a_{\mathrm{CTX}-\mathrm{M}-9 g \text { group }}$ ESBLs [26-28] and $b l a_{\mathrm{MOX}-1}, b l a_{\mathrm{MOX}-2}, b l a_{\mathrm{CMY}-1}, b l a_{\mathrm{CMY}-8}$ to $b l a_{\mathrm{CMY}-11}, b l a_{\mathrm{LAT}-1}$ to $b l a_{\mathrm{LAT}-4}$ $b l a_{\mathrm{CMY}-2}$ to $b l a_{\mathrm{CMY}-7}, b l a_{\mathrm{BIL}-1}, b l a_{\mathrm{DHA}-1}$ to $b l a_{\mathrm{DHA}-2}, b l a_{\mathrm{ACC}}, b l a_{\mathrm{MIR}-1 \mathrm{~T}}, b l a_{\mathrm{ACT}-1}$ and $b l a_{\mathrm{FOX}-1}$ to FOX-5 pAmpC encoding genes [29]. Negative and previously sequenced positive controls were included in all PCR reactions. Negative controls were PCR mixtures with the addition of water in place of template DNA.

\subsection{Statistical Analysis}

Statistical analysis was performed using SAS statistical software package for Windows, version 9.4 (SAS Institute, Cary, NC, USA). For the categorical variables, proportions were compared using Fisher's exact test and General linear model (GLM) procedures were used to perform descriptive statistics of ESBL/AmpC-producing Enterobacteriaceae load. The results were considered statistically significant when $p<0.05$.

\section{Results}

Thirty six percent $(n=9 / 25)$ of fecal samples were obtained from female dogs and $64.0 \%(n=16 / 25)$ from males, with a median age of 7 years (ranging from $0.2-13$ years). All the animals belonged to private owners. Previous hospitalization in last year was observed in $60.0 \%(n=15 / 25)$ of the dogs and $50.0 \%(n=12 / 24)$ had been treated with an antimicrobial agent within the last year. All the animals had access to the street, $68.0 \%$ $(n=17 / 25)$ and $12.0 \%(n=3 / 25)$ of the dogs cohabited with other animals and had been in shelters/hotels, respectively (Table 1 ).

About $76.0 \%(n=19 / 25)$ of the animals were submitted to soft tissues surgery and $24.0 \%(n=6 / 25)$ to orthopedic surgery. Regarding prophylactic antimicrobial treatment, $92.0 \%(n=23 / 25)$ of the dogs received prophylactic antimicrobial treatment through oral administration by different antimicrobials before and after surgery (Table 1). About $52.0 \%$ $(n=12 / 23)$ of the dogs and $73.9 \%(n=17 / 23)$ were administered AMC, before surgery and after surgery, respectively. One dog received $\mathrm{AMC}$ and a second-generation cephalosporin (2GC) after surgery; three dogs received other antimicrobials (2GC, $n=1$; AMC and metronidazole, $n=1$; metronidazole and macrolides $n=1$ ) in both time points. 
Table 1. Descriptive statistics of healthy dogs sampled $(n=25)$ in this study.

\begin{tabular}{llc}
\hline Dogs Sampled & & $\%(n)$ \\
\hline \multirow{2}{*}{ Gender } & Female & $36.0(9)$ \\
Origin & Male & $64.0(16)$ \\
& Private owner & $100.0(25)$ \\
Antimicrobial treatment in last year & Yes & $50.0(12)$ \\
& No & $46.0(11)$ \\
& No data & $4.0(1)$ \\
Hospitalization in last year & Yes & $60.0(15)$ \\
& No & $40.0(10)$ \\
Cohabitation with other animals & Yes & $12.0(3)$ \\
& No & $88.0(22)$ \\
Street access & Yes & $68.0(17)$ \\
Shelter/hotel access & No & $32.0(8)$ \\
Surgery reason & Yes & $12.0(3)$ \\
& No & $88.0(22)$ \\
Antimicrobial prophylactic treatment & Yes & $76.0(19)$ \\
& No & $24.0(6)$ \\
& Ooft tissues & $92.0(23)$ \\
\hline
\end{tabular}

In this study, $20.0 \%(n=5 / 25)$ of the dogs were colonized with ESBL-producing Enterobacteriaceae at the time of hospital admission, four of which were E. coli and one was Klebsiella pneumoniae (Table 2). The most common antimicrobial resistance phenotype of E. coli isolates was $\mathrm{AMP}^{\mathrm{R}}-\mathrm{AMC}^{\mathrm{R}}-\mathrm{KF}^{\mathrm{R}}-\mathrm{CTX}^{\mathrm{R}}-\mathrm{FOX}^{\mathrm{R}}-\mathrm{CAZ}^{\mathrm{R}}(60.0 \%, n=3 / 4)$. Two E. coli harbored the bla $a_{\mathrm{TEM}}$ gene $(n=2 / 4)$, one harbored the bla $a_{\mathrm{SHV}}$ gene $(n=1 / 4)$ and one bla $a_{\text {CTX-M-1group }}(n=1 / 4)$ (Table 2).

Regarding samples collected after surgery (AS), about $64.0 \%(n=14 / 22)$ of dogs were colonized with 3GC-resistant Enterobacteriaceae. Around $45.0 \%(n=10 / 22)$ of the fecal samples were E. coli positive, followed by K. pneumoniae $(18.2 \%, n=4 / 22)$ and E. cloacae $(13.6 \%, n=3 / 22$ ). Interestingly, in one of the fecal samples (FMVS3), several ESBL producers were found, along with one E. coli isolate and three Klebsiella pneumoniae isolates with different antimicrobial phenotypes and genotypes (Table 2).

Among the E. coli isolates, the most common antimicrobial resistance phenotype was $\mathrm{AMP}^{\mathrm{R}}-\mathrm{AMC}^{\mathrm{R}}-\mathrm{KF}^{\mathrm{R}}-{ }_{-} \mathrm{CT}^{\mathrm{R}}{ }_{-}-\mathrm{FOX}^{\mathrm{R}}-\mathrm{CAZ}^{\mathrm{R}}(n=8 / 10)$, while among $K$. pneumonia and E. cloacae the most common was $\mathrm{AMP}^{\mathrm{R}}-\mathrm{AMC}^{\mathrm{R}}-\mathrm{KF}^{\mathrm{R}}-\mathrm{CTX}^{\mathrm{R}}-\mathrm{CAZ}^{\mathrm{R}}(n=2 / 4)$ and $\mathrm{AMP}^{\mathrm{R}}-\mathrm{KF}^{\mathrm{R}}-\mathrm{CTX}^{\mathrm{R}}$ FOX $^{\mathrm{R}}-\mathrm{CAZ}^{\mathrm{R}}(n=3 / 3)$, respectively. Furthermore, $70.0 \%$ of the E. coli isolates $(n=7 / 10)$ harbored the $b l a_{\text {TEM }}$ gene, and the remaining isolates harbored the bla $a_{\mathrm{CTX}-\mathrm{M}-1 \text { group }}$ gene $(n=1 / 10)$, $b l a_{\mathrm{SHV}}$ gene $(n=1 / 10)$ and one carried the combination of $b l a_{\mathrm{OXA}-1}+b l a_{\mathrm{TEM}}$ genes (Table 3$)$. Regarding K. pneumoniae, all isolates were positive for $b l a_{\mathrm{OXA}-1}+b a_{\mathrm{TEM}}+b l a_{\mathrm{CTX}-\mathrm{M}-1 \text { group }}$ genes (Table 2). In addition to the increase in 3GC-resistant Enterobacteriaceae in fecal samples after surgery (AS), most E. coli isolates belonged to commensal phylogenetic groups (group-A, $n=4 / 10$; group-B1, $n=3 / 10$ ). Pathogenic phylogenetic groups were also detected (group$\mathrm{B} 2, n=2 / 10$; group-D, $n=1 / 10$ ) (Table 2 ). However, there was no statistically significant difference between BS and AS regarding pathogenic E. coli phylogenetic groups.

In this study, the number of dogs colonized with ESBL/AmpC-producing Enterobacteriaceae was significantly higher in the AS group $(63.6 \%, n=14 / 22)$ than in the BS group $(20.0 \%, n=5 / 25, p=0.0033)$ (Table 2). Moreover, the ESBL/AmpC-producing Enterobacteriaceae load mean after surgery was $1.74 \times 10^{6} \pm 5.33 \times 10^{6} \mathrm{CFU} / \mathrm{g}$ of feces, and before surgery it was $1.10 \times 10^{2} \pm 4.51 \times 10^{2} \mathrm{CFU} / \mathrm{g}$ of feces. The CTX-resistant bacteria fecal load was statistically significantly higher in the AS group than in the BS group $(p=0.025)$ (Table 3). 
Table 2. Genotypic and phenotypic traits of ESBL/AmpC-producing Enterobacteriaceae from healthy dogs before surgery and after surgery (AS).

\begin{tabular}{|c|c|c|c|c|c|c|c|}
\hline Animal Group & ESBLs (\%) & $p$ Value & Isolates ID & Bacteria & $\begin{array}{l}\text { Antimicrobial Resistance } \\
\text { Phenotype }\end{array}$ & $\beta$-Lactamases & E. coli Phylogroup \\
\hline \multirow{4}{*}{ Before surgery $(n=25)$} & \multirow{4}{*}{20.0} & \multirow{21}{*}{0.0033} & FMVS1 & E. coli & AMP KF CTX & $b l a_{\text {CTX-M-1group }}$ & B1 \\
\hline & & & FMVS2 & E. coli & AMP AMC KF CTX FOX CAZ & $b l a_{\mathrm{TEM}}$ & $\mathrm{D}$ \\
\hline & & & FMVS14 & E. coli & AMP AMC KF CTX FOX CAZ & $b a_{\mathrm{SHV}}$ & B1 \\
\hline & & & FMVS20 & K. pneumoniae* & AMP AMC KF CTX FOX & bla $_{\mathrm{SHV}}$ & - \\
\hline \multirow{17}{*}{ After surgery (AS) $(n=22)$} & \multirow{17}{*}{63.6} & & FMVS1 & K. pneuтопіае * & AMP AMC KF CTX CAZ & $b l a_{\mathrm{OXA}-1}, b l a_{\mathrm{TEM}}, b l a_{C T X-\mathrm{M}-1 \text { group }}$ & - \\
\hline & & & FMVS2 & E. coli & AMP AMC KF CTX FOX CAZ & bla $_{\mathrm{TEM}}$ & $\mathrm{D}$ \\
\hline & & & FMVS3a & E. coli & AMP AMC KF CTX FOX CAZ & bla $_{\mathrm{TEM}}$ & B2 \\
\hline & & & FMVS3b & K. pneumoniae * & AMP AMC KF CTX CAZ & $b l a_{\mathrm{OXA}-1}, b l a_{T E M}, b l a_{\mathrm{CTX}-\mathrm{M}-1 \text { group }}$ & - \\
\hline & & & FMVS3c & K. pneuтопіае * & AMP AMC KF CTX FOX CAZ & ${ }_{b l a} a_{\mathrm{TEM}}, b l a_{\mathrm{CTX}-\mathrm{M}-\mathrm{g} \text { group }}$ & - \\
\hline & & & FMVS3d & K. pneumoniae* & AMP AMC KF CTX & bla $a_{\mathrm{OXA}-1}$, bla & - \\
\hline & & & FMVS4 & E. cloacae ** & AMP KF CTX FOX CAZ & nd & - \\
\hline & & & FMVS6 & E. cloacae** & AMP KF CTX FOX CAZ & nd & - \\
\hline & & & FMVS7 & E. coli & AMP AMC KF CTX FOX CAZ & $b l a_{\mathrm{TEM}}$ & B1 \\
\hline & & & FMVS9 & E. coli & AMP KF CTX & bla & B2 \\
\hline & & & FMVS11 & E. coli & AMP AMC KF CTX FOX CAZ & bla OXA-1, bla TEM $_{\text {TE }}$ & A \\
\hline & & & FMVS12 & E. cloacae** & AMP KF CTX FOX CAZ & nd & - \\
\hline & & & FMVS13 & E. coli & AMP KF CTX CAZ & $b l a_{\mathrm{SHV}}$ & B1 \\
\hline & & & FMVS16 & E. coli & AMP AMC KF CTX FOX CAZ & bla TEM & A \\
\hline & & & FMVS17 & E. coli & AMP AMC KF CTX FOX CAZ & $b_{a \mathrm{TEM}}$ & A \\
\hline & & & FMVS21 & E. coli & AMP AMC KF CTX FOX CAZ & $b l a_{\mathrm{TEM}}$ & B1 \\
\hline & & & FMVS25 & E. coli & AMP AMC KF CTX FOX CAZ & $b a_{\mathrm{TEM}}$ & A \\
\hline
\end{tabular}

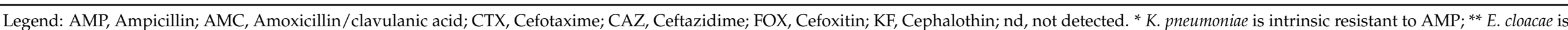
intrinsic resistant to AMP, AMC, first-generation cephalosporins, and FOX [25].

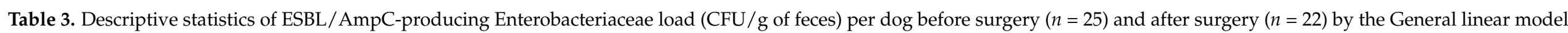
procedure.

\begin{tabular}{|c|c|c|c|c|c|c|}
\hline Animal Group & Mean (CFU/g) & SD & SE & Min (UFC/g) & $\operatorname{Max}(\mathrm{UFC} / \mathrm{g})$ & $p$ Value \\
\hline Before surgery $(n=25)$ & $1.10 \times 10^{2 \mathrm{a}}$ & $4.51 \times 10^{2}$ & $5.24 \times 10^{5}$ & 0.0 & $2.25 \times 10^{3}$ & \multirow{2}{*}{0.025} \\
\hline After surgery $(n=22)$ & $1.74 \times 10^{6 b}$ & $5.33 \times 10^{6}$ & $4.00 \times 10^{5}$ & 0.0 & $1.84 \times 10^{7}$ & \\
\hline
\end{tabular}

Legend: SD, standard deviation; SE, standard error mean; Min, minimum; Max, maximum. Mean values with a character with different letters are statistically significant $(p$ value $=0.025)$. 


\section{Discussion}

In this study, about $20.0 \%$ of dogs before surgery and before entering the hospital were already colonized with ESBL/AmpC-producing Enterobacteriaceae. The results obtained here were similar to those previously published using samples from 2010-2011 from healthy dogs [16]. It is likely that this similarity is related to the fact that both studies were conducted in the same geographical area (metropolitan region of Lisbon). A significant increase in antimicrobial resistance was detected among bacteria causing UTI in companion animals from the Lisbon area between 1999 and 2014 [30]. Therefore, the apparent stable frequency of the CTX-resistant bacteria fecal carriage among heathy dogs is considered a positive outcome from this study. Nevertheless, the frequency of colonization by CTX-resistant bacteria reported here $(20 \%)$ before surgery should not be neglected since the fecal carriage of ESBLs/AmpC-producing may be a risk factor for secondary infections by MDR bacteria in hospitalized patients, as also occurs in humans.

The ESBL/AmpC-producing Enterobacteriaceae detected in this study were E. coli, K. pneumoniae and E. cloacae. Enterobacter cloacae is ubiquitous in the environment, and it is commensal in the intestinal tract of humans and animals [31]. This species is also prone to contaminating various medical, intravenous, and other hospital devices contributing to skin/soft tissue infections, urinary tract, and intra-abdominal infections [32]. Furthermore, E. cloacae has an intrinsic resistance to ampicillin, amoxicillin, first-generation cephalosporins, and cefoxitin owing to the production of constitutive AmpC $\beta$-lactamase. Resistance of Enterobacter spp. to 3GC is, in most cases, caused by overproduction of AmpC $\beta$-lactamases [33-35].

In this study, the $b l a_{\mathrm{TEM}}$ and $b a_{\mathrm{CTX}} \mathrm{M}$-1group were the most frequent $\beta$-lactam-resistance genes, which is in agreement with previous studies [15,18,34]. Hordijk et al. [19] analyzed healthy dogs and cats without contact with the hospital environment in the Netherlands and detected a high percentage (45\%) of dogs colonized with Enterobacteriaceae-producing $\beta$-lactamases (ESBL/AmpCs). Procter et al. [35] reported that $12.7 \%$ of E. coli strains isolated from dogs, who attended parks in three cities in Canada, were resistant to $\beta$-lactam antimicrobials. Aslantas and Yilmaz [36] detected $22 \%$ of dogs were colonized by CTXresistant $E$. coli in Turkey. The different frequencies of $\beta$-lactam-resistant bacteria detected in these studies may be related to differences among geographical regions or to differences between study designs. Nevertheless, it highlights the importance of reporting data from different geographical regions.

In this study, ESBL-producing Enterobacteriaceae significantly increased between AS and BS, and changes in fecal microbiota occurred, which could be in part explained by the prophylactic use of amoxicillin-clavulanate. Moreover, in addition to antimicrobial administration, the administration of other medications and also the type of food have been identified as factors influencing fecal bacteria flora [37-39]. Furthermore, dogs food is a vehicle of ESBL and AmpC-type resistance to last-resort antimicrobials thus positioning dog food as an important source of antibiotic resistance spread [38]. Yet, in this study, these two variables were not considered in the questionnaire, as they were a limitation of the study. In future studies, it will also be important to include the type of diet and other medications, in addition to antimicrobials in order to understand the changes in the fecal flora. Another limitation of this study is the sample size; it would be interesting to increase the sample size, to enable the detection of possible risk factors in the future. Furthermore, the findings presented here regarding dog colonization by CTX-resistant bacteria are of public health and veterinary interest.

In one recent study conducted in the Netherlands using whole genome sequencing, around $43 \%$ of owned dogs were found to be persistently colonized by ESBL-producing Enterobacteriaceae (6 months) [40]. It is important to notice that van den Bunt et al. used pre-enrichment media, unlike the study presented here [37]. Therefore, the high frequency of colonized dogs by CTX-resistant bacteria detected after surgery $(64.0 \%)$ could be even higher. 
An important finding from this study is not only that the number of colonized dogs by CTX-resistant bacteria increased significantly with the antimicrobial treatment, but also that there was a significant increase in the detected fecal load (UFC/g), achieving a mean value of $1.74 \times 10^{6} \mathrm{UFC} / \mathrm{g}$. These two findings together further highlight the importance of dogs in the dissemination of resistant bacteria and emphasize the need for appropriate fecal disposal during antimicrobial prophylaxis or treatment. This finding is of great importance, not only because of the direct impact on patients, but also because resistant bacteria can be transmitted from companion animals to humans and disseminated into the environment $[1,12,14,15]$.

Future longitudinal studies should be conducted to access the evolution of the fecal CTX-resistant bacteria load over time once the antimicrobial treatment is interrupted.

ESBL/AmpC-producing Enterobacteriaceae may also spread from patient to patient due to inadequate attention to infection control measures, especially hand washing. Infections caused by Enterobacteriaceae have features that are of particular concern. These organisms are highly efficient at up-regulating or acquiring genes that code for mechanisms of antimicrobial drug resistance, especially in the presence of antimicrobial selection pressure [41].

\section{Conclusions}

The findings of the current research showed that about $20 \%$ of dogs before surgery and before entering in the hospital were already colonized with ESBL/AmpC-producing Enterobacteriaceae, mainly harboring the $b l a_{\mathrm{TEM}}$ and $b l a_{\mathrm{CTX}} \mathrm{M}$-1group genes. After elective surgery, the number of dogs colonized with ESBL/AmpC-producing Enterobacteriaceae and the mean load of ESBL/AmpC-producing Enterobacteriaceae was significantly higher than before surgery. Furthermore, ESBL-producing Enterobacteriaceae significantly increased with antimicrobial prophylactic use, and changes in fecal microbiota occurred. European and national appropriate antimicrobial surgical prophylaxis guidelines are urgently needed for the compliance of antimicrobial stewardship principles in veterinary hospitals.

Author Contributions: Conceptualization, A.B., J.C. and C.P.; methodology, A.B. and J.C.; validation, A.B., C.M. and C.P.; formal analysis, A.B. and L.T.d.G.; investigation, A.B., C.M. and J.C.; data curation, A.B. and J.C.; writing - original draft preparation, A.B. and J.C.; writing-review and editing, A.B., C.P. and L.T.d.G.; supervision, C.P.; project administration, C.P.; funding acquisition, C.P. All authors have read and agreed to the published version of the manuscript.

Funding: This research was funded by CIISA and Fundação para a Ciência e a Tecnologia through Project (UID/CVT/00276/2020), and under the grant FCT PhD SFRH/BD/113142/2015 of Adriana Belas. Part of this research is supported by COST Action CA18217-European Network for Optimization of Veterinary Antimicrobial Treatment.

Informed Consent Statement: Not applicable.

Conflicts of Interest: The authors declare no conflict of interest. The funders had no role in the design of the study; in the collection, analyses, or interpretation of data; in the writing of the manuscript, or in the decision to publish the results.

\section{References}

1. Pomba, C.; Rantala, M.; Greko, C.; Baptiste, K.E.; Catry, B.; van Duijkeren, E.; Mateus, A.; Moreno, M.A.; Pyörälä, S.; Ružauskas, M.; et al. Public health risk of antimicrobial resistance transfer from companion animals. J. Antimicrob. Chemother. 2017, 72, 957-968. [CrossRef]

2. Timofte, D.; Maciuca, I.E.; Williams, N.J.; Wattret, A.; Schmidt, V. Veterinary Hospital Dissemination of CTX-M-15 ExtendedSpectrum Beta-Lactamase-Producing Escherichia coli ST410 in the United Kingdom. MDR 2016, 22, 609-615. [CrossRef] [PubMed]

3. Tuerena, I.; Williams, N.J.; Nuttall, T.; Pinchbeck, G. Antimicrobial-resistant Escherichia coli in hospitalised companion animals and their hospital environment. J. Small Anim. Pract. 2016, 57, 339-347. [CrossRef] [PubMed]

4. WHO 7th Meeting Report of WHO Advisory Group on Integrated Surveillance of Antimicrobial Resistance (AGISAR). Available online: https:/ / apps.who.int/iris/bitstream/handle/10665/272714/WHO-NMH-FOS-FZD-18.1-eng.pdf (accessed on 21 August 2021). 
5. Prescott, J.F.; Boerlin, P. Antimicrobial use in companion animals and Good Stewardship Practice. Vet. Rec. 2016, 179, 486-488. [CrossRef] [PubMed]

6. Paterson, D.L.; Bonomo, R.A. Extended-Spectrum $\beta$-Lactamases: A Clinical Update. Clin. Microbiol. Rev. 2005, 18, 657-686. [CrossRef] [PubMed]

7. Bush, K.; Jacoby, G.A. Updated functional classification of beta-lactamases. Antimicrob. Agents Chemother. 2010, 54, 969-976. [CrossRef] [PubMed]

8. Knothe, H.; Shah, P.; Krcmery, V.; Antal, M.; Mitsuhashi, S. Transferable resistance to cefotaxime, cefoxitin, cefamandole and cefuroxime in clinical isolates of Klebsiella pneumoniae and Serratia marcescens. Infection 1983, 11, 315-317. [CrossRef] [PubMed]

9. Martínez-Martínez, L.; Calvo, J. El problema creciente de la resistencia antibiótica en bacilos gram negativos: Situación actual. Enferm. Infecc. Microbiol. Clin. 2010, 28, 25-31. [CrossRef]

10. Schmiedel, J.; Falgenhauer, L.; Domann, E.; Bauerfeind, R.; Prenger-Berninghoff, E.; Imirzalioglu, C.; Chakraborty, T. Multiresistant extended-spectrum $\beta$-lactamase-producing Enterobacteriaceae from humans, companion animals and horses in central Hesse, Germany. BMC Microbiol. 2014, 14, 187. [CrossRef]

11. Giguère, S.; Prescott, J.F.; Dowling, P.M. Textbook of Antimicrobial Therapy in Veterinary Medicine, 5th ed.; Ames, I., Ed.; Wiley Blackwell: Hoboken, NJ, USA, 2013; ISBN 978-0-470-96302-9.

12. Johnson, J.R.; Stell, A.L.; Delavari, P. Canine Feces as a Reservoir of Extraintestinal Pathogenic Escherichia coli. Infect. Immun. 2001, 69, 1306-1314. [CrossRef]

13. Barza, M.; Travers, K. Excess Infections Due to Antimicrobial Resistance: The "Attributable Fraction". Clin. Infect. Dis. 2002, 34, S126-S130. [CrossRef] [PubMed]

14. Guardabassi, L. Pet animals as reservoirs of antimicrobial-resistant bacteria: Review. J. Antimicrob. Chemother. 2004, 54, 321-332. [CrossRef] [PubMed]

15. Johnson, J.R.; Miller, S.; Johnston, B.; Clabots, C.; DebRoy, C. Sharing of Escherichia coli Sequence Type ST131 and Other MultidrugResistant and Urovirulent E. coli Strains among Dogs and Cats within a Household. J. Clin. Microbiol. 2009, 47, 3721-3725. [CrossRef] [PubMed]

16. Belas, A.; Salazar, A.S.; Gama, L.T.; Couto, N.; Pomba, C. Risk factors for faecal colonisation with Escherichia coli producing extended-spectrum and plasmid-mediated AmpC $\beta$-lactamases in dogs. Vet. Rec. 2014, 175, 202. [CrossRef]

17. Damborg, P.; Morsing, M.K.; Petersen, T.; Bortolaia, V.; Guardabassi, L. CTX-M-1 and CTX-M-15-producing Escherichia coli in dog faeces from public gardens. Acta Vet. Scand. 2015, 57, 83. [CrossRef]

18. Johnson, J.R.; Davis, G.; Clabots, C.; Johnston, B.D.; Porter, S.; DebRoy, C.; Pomputius, W.; Ender, P.T.; Cooperstock, M.; Slater, B.S.; et al. Household Clustering of Escherichia coli Sequence Type 131 Clinical and Fecal Isolates According to Whole Genome Sequence Analysis. Open Forum. Infect. Dis. 2016, 3, 129. [CrossRef]

19. Hordijk, J.; Schoormans, A.; Kwakernaak, M.; Duim, B.; Broens, E.; Dierikx, C.; Mevius, D.; Wagenaar, J.A. High prevalence of fecal carriage of extended spectrum $\beta$-lactamase/AmpC-producing Enterobacteriaceae in cats and dogs. Front. Microbiol. 2013, 4, 242. [CrossRef]

20. Haenni, M.; Saras, E.; Métayer, V.; Médaille, C.; Madec, J.-Y. High Prevalence of bla CTX-M-1 /IncI1/ST3 and bla CMY-2 /IncI1/ST2 Plasmids in Healthy Urban Dogs in France. Antimicrob. Agents Chemother. 2014, 58, 5358-5362. [CrossRef]

21. McDaniels, A.E.; Rice, E.W.; Reyes, A.L.; Johnson, C.H.; Haugland, R.A.; Stelma, G.N. Confirmational Identification of Escherichia coli, a Comparison of Genotypic and Phenotypic Assays for Glutamate Decarboxylase and beta-d-Glucuronidase. Appl. Environ. Microbiol. 1998, 64, 4113. [CrossRef]

22. Padmavathy, B.; Vinoth, K.R.; Patel, A.; Deepika Swarnam, S.; Vaidehi, T.; Jaffar, A.B.M. Rapid and Sensitive Detection of Major Uropathogens in a Single-Pot Multiplex PCR Assay. Curr. Microbiol. 2012, 65, 44-53. [CrossRef]

23. Féria, C.; Ferreira, E.J.D.; Gonçalves, J.; Caniça, M. Patterns and mechanisms of resistance to beta-lactams and beta-lactamase inhibitors in uropathogenic Escherichia coli isolated from dogs in Portugal. J. Antimicrob. Chemother. 2002, 49, 77-85. [CrossRef] [PubMed]

24. Doumith, M.; Day, M.J.; Hope, R.; Wain, J.; Woodford, N. Improved Multiplex PCR Strategy for Rapid Assignment of the Four Major Escherichia coli Phylogenetic Groups. J. Clin. Microbiol. 2012, 50, 3108-3110. [CrossRef] [PubMed]

25. CLSI. Performance Standards for Antimicrobial Susceptibility Testing, 27th Informational Supplement; Clinical and Laboratory Standards Institute: Wayne, PA, USA, 2020.

26. Edelstein, M.; Pimkin, M.; Palagin, I.; Edelstein, I.; Stratchounski, L. Prevalence and Molecular Epidemiology of CTX-M ExtendedSpectrum $\beta$-Lactamase-Producing Escherichia coli and Klebsiella pneumoniae in Russian Hospitals. Antimicrob. Agents Chemother. 2003, 47, 3724-3732. [CrossRef]

27. Pomba, C.; Mendonça, N.; Costa, M.; Louro, D.; Baptista, B.; Ferreira, M.; Correia, J.D.; Caniça, M. Improved multiplex PCR method for the rapid detection of $\beta$-lactamase genes in Escherichia coli of animal origin. Diagn. Microbiol. Infect. Dis. 2006, 56, 103-106. [CrossRef] [PubMed]

28. Woodford, N.; Fagan, E.J.; Ellington, M.J. Multiplex PCR for rapid detection of genes encoding CTX-M extended-spectrum $\beta$-lactamases. J. Antimicrob. Chemother. 2006, 57, 154-155. [CrossRef] [PubMed]

29. Perez-Perez, F.J.; Hanson, N.D. Detection of Plasmid-Mediated AmpC -Lactamase Genes in Clinical Isolates by Using Multiplex PCR. J. Clin. Microbiol. 2002, 40, 2153-2162. [CrossRef] [PubMed] 
30. Marques, C.; Belas, A.; Franco, A.; Aboim, C.; Gama, L.T.; Pomba, C. Increase in antimicrobial resistance and emergence of major international high-risk clonal lineages in dogs and cats with urinary tract infection: 16 year retrospective study. J. Antimicrob. Chemother. 2018, 73, 377-384. [CrossRef] [PubMed]

31. Davin-Regli, A.; Pag̃̃ “s, J.-M. Enterobacter aerogenes and Enterobacter cloacae; versatile bacterial pathogens confronting antibiotic treatment. Front. Microbiol. 2015, 6, 392. [CrossRef]

32. Nordmann, P.; Dortet, L.; Poirel, L. Rapid Detection of Extended-Spectrum-Lactamase-Producing Enterobacteriaceae. J. Clin. Microbiol. 2012, 50, 3016-3022. [CrossRef]

33. Potron, A.; Poirel, L.; Rondinaud, E.; Nordmann, P. Intercontinental spread of OXA-48 beta-lactamase-producing Enterobacteriaceae over a 11-year period, 2001 to 2011. Euro. Surveill. 2013, 18, 20549. [CrossRef]

34. Costa, D.; Poeta, P.; Sáenz, Y.; Coelho, A.C.; Matos, M.; Vinué, L.; Rodrigues, J.; Torres, C. Prevalence of antimicrobial resistance and resistance genes in faecal Escherichia coli isolates recovered from healthy pets. Vet. Microbiol. 2008, 127, 97-105. [CrossRef] [PubMed]

35. Procter, T.D.; Pearl, D.L.; Finley, R.L.; Leonard, E.K.; Janecko, N.; Reid-Smith, R.J.; Weese, J.S.; Peregrine, A.S.; Sargeant, J.M. A Cross-Sectional Study Examining the Prevalence and Risk Factors for Anti-Microbial-Resistant Generic Escherichia coli in Domestic Dogs that Frequent Dog Parks in Three Cities in South-Western Ontario, Canada. Zoonoses Public Health 2014, 61, 250-259. [CrossRef] [PubMed]

36. Aslantaş, Ö.; Yilmaz, E.Ş. Prevalence and molecular characterization of extended-spectrum $\beta$-lactamase (ESBL) and plasmidic AmpC $\beta$-lactamase (pAmpC) producing Escherichia coli in dogs. J. Vet. Sci. 2017, 79, 1024-1030. [CrossRef] [PubMed]

37. Dubos, R.J.; Schaedler, R.W. The effect of diet on the fecal bacterial flora of mice and on their resistance to infection. J. Exp. Med. 1962, 1, 1161-1172. [CrossRef] [PubMed]

38. Davies, R.H.; Lawes, J.R.; Wales, A.D. Raw diets for dogs and cats: A review, with particular reference to microbiological hazards. J. Small Anim. Pract. 2019, 60, 329-339. [CrossRef]

39. Vich, V.A.; Collij, V.; Sanna, S.; Sinha, T.; Imhann, F.; Bourgonje, A.R.; Mujagic, Z.; Jonkers, D.; Masclee, A.A.M.; Fu, J.; et al. Impact of commonly used drugs on the composition and metabolic function of the gut microbiota. Nat. Commun. 2020, 11, 362. [CrossRef]

40. van den Bunt, G.; Fluit, A.C.; Spaninks, M.P.; Timmerman, A.J.; Geurts, Y.; Kant, A.; Scharringa, J.; Mevius, D.; Wagenaar, J.A.; Bonten, M.J.M.; et al. Faecal carriage, risk factors, acquisition and persistence of ESBL-producing Enterobacteriaceae in dogs and cats and co-carriage with humans belonging to the same household. J. Antimicrob. Chemother. 2020, 75, 342-350. [CrossRef]

41. Rantala, M.; Lahti, E.; Kuhalampi, J.; Pesonen, S.; Järvinen, A.-K.; Saijonmaa-Koulumies, L.; Honkanen-Buzalski, T. Antimicrobial resistance in Staphylococcus spp., Escherichia coli and Enterococcus spp. in dogs given antibiotics for chronic dermatological disorders, compared with non-treated control dogs. Acta Vet. Scand. 2004, 45, 37. [CrossRef] 